\title{
PERMAINAN TRADISIONAL BOI BOIAN DALAM KOMPETENSI KALOBORASI PADA PEMBELAJARAN SEJARAH UNTUK KESIAPAN MAHASISWA IKIP BUDI UTOMO MALANG DALAM MENYONGSONG KECAKAPAN ABAD 21
}

\author{
Romaldus Boli Witin1) \\ Program Studi Pendidikan Sejarah dan Sosiologi lkip Budi Utomo Malang \\ romaldusboliwitin@gmail.com \\ Puspita Pebri Setiani 2) \\ IKIP Budi Utomo Malang \\ puspitapebrisetiani@budiutomomalang.ac.id
}

\begin{abstract}
ABSTRAK
Masalah yang dihadapi dan yang peneliti dilakukan adalah berdasarkan latar belakang masalah dapat didefinisikan masalah sebagai berikut :apakah modep pembelajaran TGT Terintegrasi permainan Boi-Boian dapat meningkatkan kompetensi kolaborasi kecakapan abad 21 dalam materi proses penyebaran adama Budha dan Hindu Indonesia di SMA Negeri 1 Wulandoni. Dalam penelitian ini peneliti mengambil data di SMA Negeri 1 Wulandoni yaitu dengan subjek penelitian siswa kelas XII IPA dan IPS, tehnik pengumpulan data dalam penelitian ini adalah berupa angket dan lembar observasi. Penelitian ini dibantu dengan menggunakan model pembelajaran TGT terintegrasi permainan Boi- boian. Penelitian ini menggunakan pendekatan penelitian kuantitatif. Berdasarkan hasil penelitian pada siswa/siswi SMA Negeri 1 Wulandoni dapat disimpulkan bahwa terdapat pengaruh signifikan yang positif pada penerapan model pembelajaran Team games tournament berbantuan dengan permainan boi-boian untuk meningkatkan kompetensi kolaborasi kecakapan abad 21 terhadap hasil belajar afektif siswa kelas XI IPS SMA NEGERI 1 WULANDONI. Selanjutnya dilakukan pengujian untuk mengetahui pengaruh perbedaan antara nilai pretest dan nilai post-test kreativitas siswa. Dari hasil pengolahan terlihat bahwa angka signifikansi untuk peubah adalah 0,000. Karena nilainya jauh di bawah 0,05 maka Ho ditolak dan $\mathrm{Ha}$ diterima. Sehingga dapat disimpulkan bahwa ada pengaruh pemberian treatmen/perlakuan pada siswa dengan model pembelajaran TGT 1.
\end{abstract}

Kata kunci : TGT, Permainan Tradisional, Boi - Boian, Kolaborasi Kecakapan Abad 21

\section{PENDAHULUAN}

Pendidikan diartikan sebagai usaha

sadar yang dilakukan oleh pendidik melalui

bimbingan, pengajaran dan latihan untuk membantu peserta didik mengalami proses diri ke arah tercapai dengan demikian, diharapkan pendidik dapat 
melakukan bimbingan serta pengajaran pada peserta didik hingga pada akhirnya peserta didik menjadi pribadi yang dewasa. Guru selain bertugas untuk mengajar yang secara umum didefinisikan menyampaikan materi pelajaran kepada siswa, guru juga dituntut untuk mampu mendidik siswa menjadi pribadi yang memiliki akhlak mulia. Berbakti kepada orang tua, guru, maupun mengabdikan diri untuk masyarakat. Pendidikan berasal dari kata dasar didik yang artinya memelihara dan member latihan, ajaran, bimbingan mengenai akhlak dan kecerdasan pikiran (KBBI:2009).

Kualitas pendidikan di Indonesia masih menjadi perhatian. Hal ini terlihat dari banyaknya kendala yang mempengaruhi peningkatan kualitas pendidikan di Indonesia, sehingga perlu diteliti dan dicermati agar kelak bangsa Indonesia dapat meningkatkan kualitas pendidikan dengan lancar dan dapat bersaing di Era Globalisasi. Rendahnya mutu atau kualitas pendidikan di samping disebabkan oleh karena pemberian peranan yang kurang proporsional terhadap sekolah, kurang memadainya perencanaan, pelaksanaan, dan pengelolaan sistem kurikulum, dan penggunaan prestasi hasil belajar secara kognitif sebagai satu - satunya indikator keberhasilan pendidikan, juga disebabkan oleh sistem evaluasi yang tidak secara berencana sebagai alat pendidikan dan bagian terpadu dari sistem kurikulum ( Soedijarto 1991: 56 ).

Dengan melihat keadaan mutu pendidikan yang rendah, maka diupayakan usaha - usaha dalam meningkatkan mutu pendidikan. Upaya yang perlu ditingkatkan ( Zamroni 2001 : 51) adalah absensi dan kedisiplinan guru, membentuk teacher meeting, mengikuti penataran, manajemen pengelolaan pendidikan, perbaikan kurikulum, mengikuti kursus pendidikan, mengadakan lokakarya dan study tour.

Agar proses pembelajaran dapat berjalan secara efektif dan efisien dan terdapat peningkatan kompetensi kolaborasi siswa maka diperlukan kegiatan pembelajaran yang berpusat pada siswa dengan memberikan kesempatan kepada siswa untuk melakukan aktivitas sendiri. Maka dari itu, sebagai seorang guru harus berinteraksi dengan siswa dan juga memiliki kemampuan menggali metode dalam pembelajaran dan menciptakan model - model baru sehingga murid tidak mengalami kejenuhan dan bisa tercapainya tujuan pembelajaran (Shoimin 2014 : 20). Salah satu model pembelajaran aktif yang digunakan peneliti adalah model 
pebelajaran tipe Team Games Tournament ( TGT ).

Model pembelajaran Teams Games Tournament (TGT) menurut Mulyatiningsih (2014 : 244) adalah salah satu tipe atau model pembelajaran koomperatif yang mudah diterapkan. Penerapan model pembelajaran koomperatif tipe TGT merupakan salah satu upaya untuk meningkatkan aktivitas belajar siswa tanpa harus ada perbedaan status, melibatkan peran siswa sebagai tutor sebaya dan mengandung unsur permainan dan reinforcement. Aktivitas belajar dengan permainan yang dirancang dalam pembelajaran koomperatif model Teams Games Tournament (TGT) memungkinkan siswa dapat belajar lebih rileks disamping menumbuhkan tanggung jawab, kejujuran, kerja sama, persaingan sehat, dan keterlibatan belajar. Pada model ini siswa memainkan permainan boi-boian dengan anggota-anggota tim lain untuk memperoleh tambahan poin untuk skor tim mereka.

Pada umumnya dalam menerapkan model pembelajaran tipe Teams Games Tournament (TGT) dipadukan dengan permainan tradisional, siswa cenderung lebih menyukai atau tertarik pada olahraga atau aktivitas jasmani yang bersifat permainan yang dilakukan secara berkelompok. Salah satu permainan yang dilakukan secara berkelompok yang banyak disukai oleh anak-anak adalah permainan boi-boian.

Permainan boi-boian sendiri merupakan salah satu dari sekian banyak permainan tradisional di Indonesia. Dimana permainan tradisional merupakan hasil penggalian dari budaya sendiri yang didalamnya banyak mengandung nilai-nilai pendidikan karena dalam kegiatan permainanya memberikan rasa senang, gembira, ceria pada anakanak yang memainkanya. Selain itu permainanya dilakukan secara berkelompok sehingga menimbulkan rasa demokrasi antara teman mai dan alat permainan yang digunakan pun relatif sederhana (BP-PLSP,2006).

Beberapa riset membuktikan bahwa peserta didik dapat memiliki peningkatan kompetensi kolaborasi dan belajar dengan lebih baik jika mereka secara aktif terlibat pada proses pembelajaran dalam suatu kelompok-kelompok kecil. Peserta didik yang bekerja dalam kelompok-kelompok kecil cendrung belajar lebih banyak tentang materi ajar dan mengingatnya lebih lama dibandingkan jika materi ajar tersebut dihadirkan dalam bentuk lain, misalnya bentuk ceramah, tanpa 
memandang bahan ajarnya (Warsono dan Hariyanto, 2012 : 66-67).

Sebagai seorang guru, khususnya guru Sekolah Menengah Atas haruslah pandai-pandai memilah dan memilih macam dan bentuk permainan dalam proses pembelajaran. Hal ini disesuaikan dengan karakteristik siswa SMA yang tidak gemar bermain. Dengan metode pembelajaran menggunakan pendekatan bermain, secara tidak langsung guru dapat memasukan materi inti, sehingga pada akhir pembelajaran siswa mampu menguasai materi yang diajarkan guru. Pada permainan tradisional boi-boian, siswa dipacu untuk dapat bergerak dengan kecepatan, dan mengatur strategi. Dengan aktivitis yang demikian ini diharapkan agar proses belajar dengan model pembelajaran Temas Games Tournament (TGT) dipadukan dengan bermain boiboian mampu meningkatkan kompetensi kolaborasi siswa dalam menyelesaikan soal yang diajarkan.

Metode mempunyai andil yang cukup besar dalam kegiatan belajar mengajar. Kemampuan yang diharapkan dapat dimiliki anak didik, akan ditentukan oleh kerelevensian penggunaan suatu metode yang sesuai dengan tujuan. Itu berarti tujuan pembelajaran akan dicapai dengan penggunaan metode yang tepat, sesuai dengan standar keberhasilan yang terpatri dalam suatu tujuan. Metode yang dapat dipergunakan dalam kegiatan belajar mengajar bermacam-macam.

Penggunaanya tergantung dari rumusan tujuan. Dalam mengajar, jarang ditemukan guru menggunakan satu metode yang berhubungan dengan permainan tradisional. Penggunaan metode yang digabungkan dengan permainan tradisional dimaksudkan untuk menggairahkan belajar anak didik serta melestarikan kebudayaan dari permainan tradisional tersebut tetapi juga untuk meningkatkan kompetensi kolaborasi antara siswa. Dengan bergairahnya belajar dipadukan dengan permainan tradisional, anak didik tidak sukar untuk mencapai tujuan pengajaran. Karena bukan guru yang memaksakan anak didik untuk mencapai tujuan, tetapi anak didiklah yang dengan sadar untuk mencapai tujuan.

Pembelajaran di Abad ke-21 sekarang ini hendaknya disesuaikan dengan kemajuan dan tuntutan yang ada. Salah satu pembelajaran yang mungkin dapat dilakukan adalah pembelajaran yang berpusat pada siswa. Pembelajaran yang berpusat pada siswa berbeda dengan cara tradisional yaitu pembelajaran yang berpusat pada guru, 
dalam arti bahwa keduanya mempunyai pendekatan berbeda dalam isi, instruksi, lingkungan kelas, penilaian, dan teknologi. Pada kecakapan abab ke-21 para peserta didik mengerjakan tugas-tugas rumit dan penuh tantangan yang mengharuskan mereka berpikir tentang pelajaran secara mendalam dan mengatur cara belajar mereka sendiri, bekerjasama dengan teman, guru, dan para pakar dalam tugastugas penting dengan menggunakan pemikiran tingkat tinggi,menggunakan teknologi untuk membuat keputusan, memecahkan masalah, dan menciptakan gagasan baru. Untuk membantu para siswa mencapai tingkat partisipasi penuh di masyarakat, guru harus memusatkan perhatian pada kecakapan-kecakapan di abad ke-21 dan membantu para siswa beradaptasi terhadap perubahan sosial dan teknologi ( Ekawati, 2011 ).

Pembelajaran Abad 21 merupakan pembelajaran yang mengintegrasikan kemampuan literasi, kecakapan pengetahuan, keterampilan dan sikap, serta penguasaan terhadap teknologi, dan merupakan pendidikan yang mengintegrasikan antara kecakapan pengetahuan, keterampilan, dan sikap, serta penguasaan terhadap TIK.Kecakapan abad ke-21 juga terkait dengan kolaborasi dalam pembelajaran antara lain sebagai berikut; memiliki kemampuan dalam kerjasama berkelompok; beradaptasi dalam berbagai peran dan tanggungjawab, bekerja secara produktif dengan yang lain ; memiliki empati dan menghormati perspektif berbeda ; mampu berkompromi dengan anggota yang lain dalam kelompok demi tercapainya tujuan yangbtelah ditetapkan. Kecakapan tersebut dapat dikembangkan melalui berbagai model pembelajaran berbasis aktivitas yang sesuai dengan karakteristik kompetensi dan materi pembelajaran. Kecakapan yang dibutuhkan di Abad 21 juga merupakan keterampilan berpikir lebih tinggi (Higher Order Thinking Skills (HOTS) yang sangat diperlukan dalam mempersiapkan peserta didik dalam menghadapi tantangan global (Ekawati, 2011.)

SMA 1 Negeri Wulandoni merupakan satu-satunya SMA Negeri yang ada di kecamatan Wulandoni, yang didirikan oleh pemerintah kabupaten lembata pada tahun 2014. Sekolah tersebut adalah program dari pemerintah dalam memberikan ppendidikan gratis bagi masyarakat yang tidak mampu tetapi berprestasi. Berdasarkan hasil wawancara melalui via telepon dengan salah satu $\mathrm{tt}$ enaga pendidik di SMA Negeri 1 Wulandoni, diketahui bahwa proses 
belajar mengajar di SMA N 1 Wulandoni ini, guru dalam menyampaikan materi masih menggunakan metode ceramah, diskusi dan penugasan. Hal ini membuat pembelajaran kurang efektif karena siswa kurang merespon terhadap pembelajaran yang disampaikan, pengajaran semacam ini cenderung menyebabkan kebosanan kepada siswa serta aktivitas siswa kurang terbangun.

\section{METODE}

Metode penelitian pada dasarnya merupakan cara ilmiah untuk mendapatkan daya dengan tujuan dan kegunaan tertentu, serta dapat ditemukan, dikembangkan dibuktikan kevalidan data tersebut (Sugiyono, 2014:2). Metode penelitian yang dilakukan dalam penelitian ini adalah metode penelitian Eksperimen Quasi dengan pendekatan kuantutatif. Sugiyono, (2014:7) mengemukakan bahwa "metode penelitian kuantitatif disebut juga sebagai metode positvistik karena berdasarkan pada filsafat positifisme. Metode ini sebagai metode ilmiah atau scientific karena telah memenuhi kaidah-kaidah ilmiah yaitu kongkrit atau empiris,obyaktif, teruku, rasional, dan sistematis. Metode ini juga disebut metode discovery, karena dengan metode ini dapat ditemukan dan dikembangkan berbagai iptek baru.

\section{HASIL DAN PEMBAHASAN}

\section{Pembelajaran di kelas kontrol}

Penelitian diawali dengan pemberian pre-test terhadap siswa. Setelah pre-test, selanjutnya siswa kelas kontrol diajarkan dengan menerapkan model pembelajaran cermah (Konvensional) dengan metode tanya jawab. Selama pelaksanaan pembelajaran, peneliti yang bertindak sebagai guru dibantu oleh observer, dengan tujuan untuk melihat dan mencatat hasil observasi mengenai ketererlaksanaan pembelajaran dari kegiatan pendahuluan sampai kegiatan penutup. Pelaksanaan pembelajaran pada kelas kontrol selama 2 kali pertemuan (4 jam pelajaran) materi Hindu-Budha di Indonesia terdapat dalam pembelajaran kelas XI IPS semester II. Instrumen penelitian yang digunakan adalah angket yang harus disebarkan kepada seluruh siswa, khususnya kepada siwa/siswi kelas XI IPS 1 yang berjumlah 28 orang dan XI IPS 2 yang berjumlah 26 orang. Setelah selesai pembuatan angket, maka angket akan disebarkan dan harus diisi oleh siswa/siswi kelas XI IPS 1 dan XI IPS 2 dengan baik dan jujur. 
Budha Indonesia terdapat dalam pembelajaran kelas XI IPS semester II. Instrumen penelitian yang digunakan adalah angket yang harus disebarkan kepada seluruh siswa, khususnya kepada siwa/siswi kelas XI IPS 1 yang berjumlah 28 orang dan XI IPS 2 yang berjumlah 26 orang. Setelah selesai pembuatan angket, maka angket akan disebarkan dan harus diisi oleh siswa/siswi kelas XI IPS 1 dan XI IPS 2 dengan baik dan jujur.

\section{Pembelajaran di kelas eksperimen}

Pelaksanaan penelitian diawali dengan pemberian pre-test terhadap siswa. Setelah pre-test, selanjutnya siswa kelas eksperimen diajarkan dengan model pembelajarn Team games tournamentterintegrasi dengan permainan boi - boian pada materi proses masuk dan berkembangnya agama Hindu-Budha di Indonesia. Selama pelaksanaan penelitian, peneliti yang bertindak sebagai guru dibantu oleh observer, dengan tujuan untuk melihat dan mencatat hasil observasi mengenai ketererlaksanaan penerapan model pembelajarn Team games tournamentterintegrasi dengan permainan boi - boian dikelas eksperimen. Lembar observasi terdiri dari lembar observasi guru dan lembar observasi siswa. Pelaksanaan pembelajaran pada kelas eksperimen selama 2 kali pertemuan (4 jam pelajaran).

Model Teams Games Tournament (TGT ini merupakan versi sederhana dari "Turnamen-permainan-tim" yang dikembangkan oleh Robbert Slavin dan rekan-rekannya. Teknik ini menggabungkan kelompok belajar dan kompetisi tim, dan bisa digunakan untuk meningkatkan pembelajaran beragam fakta, konsep, dan keterampilan. (Silberman, 2011:171).

Penerapan model pembelajaran TGT terintegrasi permainan boi-boian pada kelas eksperimen dilakukan setelah pre-test dan telah dilakukan uji normalitas dan homogenitas, diketahui bahwa data berdistribusi normal dan homogen. Selanjutnya dengan menerapakan model pembelajaran Team Games Tournament dengan tahapan sebagai berikut Guru memberikan penjelasan tentang Proses Penyebaran Agama dan Kebudayaan Hindu-Buddha Indonesia, Guru menjelaskan langkah-langkah permainan Boi-boian, Guru membagiSiswa dalam 2 tim, minimal 8 orang setiap timnya yaitu tim A dan $B$, Guru meminta setiap perwakilan dari kedua tim melakukan hompimpa untuk menentukan tim mana yang pertama memulai permainan Boi-boian, Guru membantu siswa untuk menyusun batu 
yang sudah diselipi kertas pertanyaan, Siswa yang tidak termasuk dalam kedua tim bermain, diminta untuk mengamati permainan Boi yang dimainkan oleh tim $\mathrm{A}$ dan $B$, masing-masing tim diminta untuk melakukan permainan Boi secara Bergantian dalam kurun Waktu 15 menit per tim, bagi kelompok yang menang akan memberikn pertanyaan kepada kelompok yang kalah sesuai dengan materi pengaruh Agama dan kebudayaan HinduBuddha di Indonesia.

Setelah permainan selesai, siswa dibantu guru untuk menyimpulkan materi pengaruh Agama dan kebudayaan HinduBuddha di Indonesia, yang sudah diperankan oleh kedua tim dalam permainan Boi, Guru menyuruh siswa membuat tugas tentang berperilaku(jujur, disiplin, tanggung jawab, peduli, santun, gotong royong, kerjasama, dan menunjukan sikap sebagai bagian dari solusi atas berbagai permasalahan dalam materi proses penyebaran agama dan kebudayaan Hindu-Buddha di Indonesia, dalam bentuk angket dan lembar observasi.

Terakhir guru mengakhiri pelajaran dengan mengucap salam, pertanyaan, Siswa yang tidak termasuk dalam kedua tim bermain, diminta untuk mengamati permainan Boi yang dimainkan oleh tim $\mathrm{A}$ dan $B$, masing-masing tim diminta untuk melakukan permainan Boi secara Bergantian dalam kurun Waktu 15 menit per tim, bagi kelompok yang menang akan memberikn pertanyaan kepada kelompok yang kalah sesuai dengan materi pengaruh Agama dan kebudayaan HinduBuddha di Indonesia, Setelah permainan selesai, siswa dibantu guru untuk menyimpulkan materi pengaruh Agama dan kebudayaan Hindu-Buddha di Indonesia, yang sudah diperankan oleh kedua tim dalam permainan Boi, Guru menyuruh siswa membuat tugas tentang berperilaku(jujur, disiplin, tanggung jawab, peduli, santun, gotong royong, kerjasama, dan menunjukan sikap sebagai bagian dari solusi atas berbagai permasalahan dalam materi proses penyebaran agama dan kebudayaan Hindu-Buddha di Indonesia, dalam bentuk angket dan lembar observasi.

\section{KESIMPULAN}

Berdasarkan hasil penelitian dan pembahasan, maka dapat disimpulkan bahwa terdapat pengaruh signifikan yang positif pada penerapan model pembelajaran Team games tournament berbantuan dengan permainan boi - boian 
Terhadap kompetensi kolaborasi kecakapan abad 21 terhadap hasil belajar afektif siswa kelas XI IPS SMA NEGERI 1

WULANDONI. Hal tersebut dibuktikan dari hasil uji t menunjukkan bahwa dari output data terlihat bahwa angka signifikansi untuk peubah adalah 0,000 , karena nilai Sig. $<0,05$ maka $\mathrm{HO}$ ditolak dan $\mathrm{Ha}$ diterima. Hal ini berarti bahwa pada tingkat kepercayaan $95 \%$. Selanjutnya dilakukan pengujian untuk mengetahui pengaruh perbedaan antara nilai pre-test dan nilai post-testkreativitas siswa. Dari hasil pengolahan terlihat bahwa angka signifikansi untuk peubah adalah 0,000 . Karena nilainya jauh di bawah 0,05 maka Ho ditolak dan Ha diterima. Sehingga dapat disimpulkan bahwa ada pengaruh pemberian treatmen/perlakuan pada siswa dengan model pembelajaran TGT Terintergrasi Permainan Tradisional Boiboian. Terhadap Kompetensi Kolaborasi Kecakapan Abad 21 Dalam Materi Proses Penyebaran Agama dan Kebudayaan
Hindu-Buddha Indonesia di SMA Negeri 1

Wulandoni Kecamatan Wulandoni

Kabupaten Lembata.

\section{DAFTAR RUJUKAN}

BP-PLSP. 2006. Model Pembelajaran PAUD Melalui Permainan Tradisional. Jakarta.

Depdiknasiri: BP-PLSP Shoimin, Aris. 2014. 68 Model Pembelajaran INOVATIF dan Kurikulum 2013. Yogyakarta : AR-RUZZ MEDIA.

Silberman, M. 2011. Active Learning 101 Strategi Pembelajaran Aktif. Yogyakarta

Sugiyono. 2014. Metode Penelitian Kuantitatif Kualitatif dan R\&D. Bandung : Alfabeta.

Warsono dan Hariyanto. 2012. Pembelajaran Aktif Teori dan Asemen. Bandung : Remaja Rosdakarya.

Zamroni. 2001. Paradigma Pendidikan Masa Depan. Yogyakarta: Biografi Publishing. 